\title{
Soil water infiltration affected by topsoil thickness in row crop and switchgrass production systems
}

\begin{abstract}
Conversion of annual grain crop systems to biofuel production systems can restore soil hydrologic function; however, information on these effects is limited. Hence, the objective of this study was to evaluate the influence of topsoil thickness on water infiltration in claypan soils for grain and switchgrass (Panicum virgatum L.) production systems. The experiment was performed at the University of Missouri South Farm $\left(38^{\circ} 54^{\prime} \mathrm{N}, 92^{\circ} 16^{\prime} \mathrm{W}\right)$ on a Mexico silt loam (Vertic Luvisols) soil. Since 2009, plots were planted with either switchgrass or a corn (Zea mays L.)-soybean (Glycine max (L.) Merr.) rotation. Infiltration rates were measured using ponded infiltrometers during two years (2014 and 2015) under switchgrass and grain crop management each with two levels of topsoil thickness $(0$ and $37.5 \mathrm{~cm})$. Physically-based Parlange and Green-Ampt infiltration models were used to estimate saturated hydraulic conductivity (Ks) and sorptivity (S) parameters. Switchgrass planted on degraded soil (shallow topsoil treatment) resulted in greater Ks, S, qs (quasi-steady infiltration rate) and Kfs (field-saturated hydraulic conductivity) values than with row crop management for both 2014 and 2015 measurement years. Results for selected 24-hour mean frequency $(11.8,14.2$, and $16.2 \mathrm{~cm})$ storms showed that switchgrass production systems enhanced estimated water infiltration, reduced estimated runoff, and decreased estimated time from water ponding to end of ponding compared with row crop management. Switchgrass is recommended to be planted on degraded soils especially in claypan landscapes for improved water use.
\end{abstract}

Keyword: Claypan; Green-Ampt equation; Parlange equation; Saturated hydraulic conductivity; Biofuel crop; Surface runoff 
